\title{
E-Navigation in the Straits of Malacca and Singapore
}

\author{
Wan Siti Adibah Wan Dahalan, Zinatul A. Zainol, Jady@Zaidi Hassim, and Chia Huey Ting
}

\begin{abstract}
The Straits of Malacca and Singapore are national asset to the strait states (Malaysia, Indonesia and Singapore). Strategically, economically and environmentally significant, the strait states must be proactive in protecting and preserving the Straits. In June 2005, e-navigation system, known as Marine Electronic Highway (MEH) has been started to be implemented in the Straits of Malacca and Singapore. Its main purpose is to reduce the number of accidents of ships and to promote marine environmental protection along the waterway. The purpose of this paper is to assess the implementation and challenges of MEH. The finding reveals that combining MEH and traditional navigation aids is the best approach to reduce accidents and marine pollution in the Straits.
\end{abstract}

Index Terms-The straits of malacca and singapore, e-navigation, safety of navigation.

\section{INTRODUCTION}

The Straits of Malacca and Singapore, considered the busiest waterway in the world, represent a vital trade and communication link to the international shipping community connecting the Indian Ocean with the South China Sea and the Pacific Ocean, linking the major Asian economies of India, China, Japan, South Korea and ASEAN with the rest of the world [1], [2]. But, there is no historic international agreement binding this waterway [1]. The increase in international trade has resulted in a commensurate increase in the volume of commercial traffic through the Straits [2], [3]. In 2008, 76,381 ships have been reported at the Klang Vessel Traffic Reporting System [3]. More than 50\% of accidents occurred in the Straits are related to collisions within the Traffic Separation Scheme (TSS) [3, 4]. The Malaysian Marine Department reported that on average, there are 2 vessel accidents cases in the Straits each year [3]. The Straits' e-navigation system, Marine Electronic Highway (MEH) was introduced in 2005 and will be fully operational by 2012 .

\section{E-NAVIGATION}

According to the International Association of Marine Aids to Navigation and Lighthouse Authorities (IALA), e-navigation is the "harmonisation of marine navigation

Manuscript received September 4, 2012; revised November 18, 2012. This work was supported in part by Universiti Kebangsaan Malaysia under Grant DIPM043-2011 and GPP -2011-017

Wan Siti Adibah Wan Dahalan, Jady@Zaidi Hassim, and Chia Huey Ting are with the Faculty of Law, Universiti Kebangsaan Malaysia, 43600 UKM Bangi, Malaysia (e-mail: wsa@ukm.my,jady@ukm.my).

Zinatul A. Zainol is with the Faculty of Law, Universiti Kebangsaan Malaysia, 43600 UKM Bangi, Malaysia. She is the head of Biodiversity and Biotechnology Governance Research Group at UKM (e-mail: shiqin@ukm.my). systems and supporting shore services driven by user needs" [5]. E-navigation collects, integrates, exchanges, presents and analyses maritime information onboard and ashore by electronic means so as to enhance berth to berth navigation and related services, thus, ensuring safety and security at sea and protects the marine environment [6].

E-navigation plays a significant role in improving maritime safety and reducing the risks of accident at sea and possible environmental damage [7]. It simplifies the electronic administration of information onboard the ship and ashore and improves the efficiency and reduces costs for the maritime transport [7]. The management of vessel traffic and related services from ashore are enhanced through better provision, co-ordination, and exchange of comprehensive data in formats that is more easily understood and utilized by shore-based operators in support of vessel safety and efficiency [8]. Additionally, its authorized seamless information significantly reduces a single person error and are useful for many parties; transfer onboard ship, between ships, between ship and shore, and between shore authorities and other parties [8].

E-navigation system uses seven technologies and services - Automatic Identification System (AIS), Electronic Chart Display and Information Systems (ECDIS), Integrated Bridge Systems /Integrated Navigation Systems (IBS/INS), Automatic Radar Plotting Aids (ARPA), Radio Navigation, Long Range Identification and Tracking (LRIT) systems, Vessel Traffic Services (VTS) and the Global Maritime Distress and Safety System (GMDSS) [9]. Apart from the Straits of Malacca and Singapore, e-navigation is also available in the Baltic, Western Indian Ocean, Black Sea and Eastern Canada.

\section{Marine Electronic Highway (MEH) Project In the STRAITS OF MALACCA AND SINGAPORE}

In September 2005, the three Straits states, i.e. Malaysia, Indonesia, Singapore, together with the International Maritime Organization (IMO) and International Hydrographic Organization (IHO) signed a Memorandum of Understanding on Marine Electronic Highway (MEH) [10]. There is also cooperative arrangement and partnership between the three straits States with the Republic of Korea, the International Association of Independent Tanker Owners (INTERTANKO) and the International Chamber of Shipping (ICS) [11].

Information on MEH in the Straits are available at the IMO website and MEH website. The MEH project covers the Straits of Malacca and Singapore as the straits form the main passage connecting the Indian Ocean with the South China Sea [11]. The intention of MEH is to create an integrated system of physical infrastructure, hardware and software, 
processes and resources to improve the safety of navigation and the protection and prevention of marine pollution in the congested seas [12]. The Straits have witnessed some ship wrecks which pose a threat to navigation [13].

The MEH project in the Straits cost $\$ 6.86$ million of grant agreement between the Global Environment Facility (GEF), World Bank and IMO [10]. The project office is at Batam, Indonesia, while MEH Project Manager is based at the International Maritime Organization, London.

Built upon a network of ENCs using electronic chart display and information systems (ECDIS) and environmental management tools, all combining in an integrated platform covering the region, $\mathrm{MEH}$ allows the maximum of information to be made available both to ships and shipmasters as well as to shore-based users, such as vessel traffic services [11]. It is expected that MEH will be fully operational by 2012. Currently, the following facilities and information technologies are in place - Vessels Traffic System (VTS), Radar System, Electronic Navigation Charts (ENCs), Differential Global Positioning System (DGPS) Broadcast Service, Mandatory Ship Reporting System (STRAITREP), Ship Routeing System, Global Maritime Distress Safety System (GMDSS), Geography Information System (GIS)-based Environmental Database and Oil Spill Trajectory Model along the Straits of Malacca [11].

These facilities and technologies are installed to enhance maritime services, to improve navigational safety and security and to promote marine environmental protection and preservation. Shore-based facilities are also implemented in the Straits of Malacca and Singapore to monitor ship movement passing through either in transit or calling port. For instance, it is mandatory for all vessels entering the Straits to call the Vessel Traffic System authority on VHF channel. But in addition to technical infrastructure, economic, legal and institutional mechanisms are equally important so that public welfare, i.e. safety and health is not compromised [11].

Prior to the MEH project, the Straits states have incurred tremendous financial costs in enhancing the safety of navigation and the protection of the marine environment of the Strait. Between 1984 and 1993, The Royal Malaysian Navy spent approximately RM 70 million for hydrograph-related services, that is, surveys, charting, tide tables production, notices to mariners and others in the Straits of Malacca. The government of Malaysia spent RM 180 million to purchase two hydrographic vessels which were essential to hydrographic activities. In 2008, the Malaysian government spent more than RM 200 million to provide and maintain various aids to navigation in the strait [14]. The $\mathrm{MEH}$ project is considered as a technological network and cooperative partnership, reflecting Article 43 of the 1982 Law of the Sea Convention (LOSC). Article 43 states that:

User States and States bordering a strait should by agreement co-operate a) in the establishment and maintenance in a strait of necessary navigational and safety aids or other improvements in aid of international navigation; and $b$ ) for the prevention, reduction and control of pollution from ships [15].

\section{Challenges}

E-navigation is a concept to support humans with the management of information to improve good decision making [16]. No matter how advance the technology used in navigation are, it still relies heavily on seafaring professional to control or give instruction. Seafaring professional should be equipped with the latest knowledge in navigation technology. They need to know how to monitor, read and control the radar and satellite, as previously they only use compass [11]. Therefore, e-navigation should support man machine interface, to ensure good situational awareness and facilitate consistently good decision-making. Seafaring own skills is essential to the navigational safety of the ship, and the bridge team is the main backup to the safe functioning of the ship. This should be reflected in the training of seafaring professional [17], [18].

In addition, the issue of standardized controls and common performance standard of e-navigation systems and navigational tools need to be considered during the implementation e-navigation. Currently, no single institution is taking the lead in developing a comprehensive vision for e-navigation. Lack of standardization ashore and onboard may hamper the future development of the global shipping industry.

It is likely that e-navigation would have financial impact on individual vessels and ships owners. They have to install the relevant navigational tools on their ships and small fishing ship may find this burdensome. Moreover, Malaysia has to pay for the maintenance cost of the navigational tools except for the light dues where Malaysia is allowed to collect light dues from every ship which in the course of a voyage enters any port or place within Peninsular Malaysia [19].

Another challenge is the breakdown of the electronic supply as e-navigation depends fully on electronic supply. Basic knowledge on traditional aids to navigation for safety purposes is still important.

\section{CONCLUSION}

The initiative of e-navigation will reduce navigational errors such as shipping accidents and ship-sourced marine pollution in the Straits of Malacca and Singapore. It offers a lot of convenience to Malaysia in monitoring the vessel passing by the Straits. E-navigation should not be viewed as replacing traditional aids of navigation. Instead, e-navigation should come with traditional aids to navigation as electronic positioning signals are not failure-free. Traditional aids to navigation are still important and its combination with e-navigation may be the best approach.

\section{ACKNOWLEDGMENT}

The authors thank Universiti Kebangsaan Malaysia for supporting this research under UKM-DIPM043-2011 and GPP -2011-017 grants.

\section{REFERENCES}

[1] M. George, "Legal regime of the straits of malacca and singapore," 2008.

[2] Official website of the Maritime Institute of Malaysia. March 2011. [Online]. Available: http://www.mima.gov 
[3] Official website of the Marine Institute of Malaysia. [Online]. Available: http://www.marine.gov.my

[4] H. M. Ibrahim, "Straits Safety not just littoral states' burden," New Straits Times, pp. 22, November 2008.

[5] International Association of Marine Aids to Navigation and Lighthouse Authorities (IALA), China, 2006

[6] Report of the e-navigation working group, Report to the Maritime Safety Committee Navy, pp. 41

[7] Norwegian Ministry of Fisheries and Coastal affairs, May 2010.

[8] Key outcomes of e-navigation, Report to the Maritime Safety Committee Navy, pp. 42

[9] Work Programme, Development of an E-Navigation strategy, submitted by Japan, Marshall Islands, the Netherlands, Norway, Singapore, the United Kingdom and the United States, Maritime Safety Committee, $81^{\text {st }}$ session, Agenda item 23 MSC 81/23/11, 19.12.2005

[10] National Marine Protected Area Center. [Online]. Available: http://www.mpa.gov

[11] Meh-Project. (April 2011). [Online]. http://www.meh-project.com/project-framework
[12] Kingsford Legal Centre - Centres | UNSW LAW. [Online]. Available: http://www.austlii.edu.au

[13] Ship wreck are also within the scope of the six projects addressed by the strait States in the Symposium on the Enhancement of Safety of navigation and the Environmental Protection of the Straits of Malacca and Singapore in 2007

[14] A. Hamzah, "The straits of malacca:international cooperation in trade," Funding and Navigational Safety, 1997

[15] Article 43 Law of the Sea Convention 1982

[16] The International Maritime Human Element Bulletin, 24 September 2010

[17] P. David, "Introducing the e-navigation revolution," Nautical Institute

[18] Meh-Project and Project-Components. [Online]. Available: http://www.meh-project.com/project-components

[19] Para. 9 Need or compelling need, Work Programme, Development of an E-Navigation strategy, submitted by Japan, Marshall Islands, the Netherlands, Norway, Singapore, the United Kingdom and the United States, Maritime Safety Committee, $81^{\text {st }}$ session, Agenda item 23 MSC 81/23/11, 19.12.2005 and Section 3 Federation Light Dues Act 1953 (Act 520) 